\title{
Hydraulic Advantage of Piano-key Weir Over Ogee Weir
}

\author{
T.R. Neelakantan, T. Rajeshwaran and G. N. Renganathan
}

\begin{abstract}
The piano-key weir is a new encouraging hydraulic structure yet to become a widespread usage due to limited knowledge of the hydraulic performance. A laboratory investigation on the hydraulic efficiency of the piano-key weir was compared with that of an ogee weir. The experiment data confirmed that the piano-key weir discharged more than ogee weir for the same upstream head. However, the coefficient discharge of the piano-key weir is extremely low compared to the ogee weir.
\end{abstract}

Keywords : hydraulic performance, labyrinth, piano-key, weir

\section{INTRODUCTION}

$\mathrm{D}$ ams and reservoirs are the inherent elements of current society. Water stored in reservoirs is used for many purposes like drinking, irrigation and hydropower generation. The safety of dams is a critical issue in many cases as a dam break may cause very heavy damage to the life of people and other assets in the downstream area. Weir or spillway is a safety part provided in the dam structure to release the flood safely. Weirs are a common and useful hydraulic structure for a wide range of applications (e.g., canals, ponds, rivers, reservoirs, and others). Many existing spillways utilize a type of weir as the flow control structure. The discharge capacity of a spillway or weir depends on the geometry of the spillway or weir and head causing flow over the spillway. Due to changes in the climate influenced by global warming and the improvement in the availability of historical data at many dam sites, re-evaluation of the safety of spillway or weir and thus the whole reservoir becomes essential.

A labyrinth form, increasing the effective weir length, gives an exciting solution to increase discharges by maintaining the width of conventional weirs. A labyrinth weir is a linear weir folded in plan-view; this structural form presents several advantages when compared to linear weir structures. Piano-key Weir is a special type of labyrinth weir. Piano-key weir was given the name from its geometry (refer Fig. 3). Piano-key weir extends the benefits of the labyrinth weirs while it is cheaper. The presence of cantilevers in the folds reduces the volume of concrete, and the compact geometry allows the use of prefabrication, and thus they reduce the cost

Revised Manuscript Received on December 30, 2019.

* Correspondence Author

T.R. Neelakantan*, Department of Civil Engineering, Kalasalingam Academy of Research and Education, Krishnankoil 626126, India, neelakantan@klu.ac.in

T. Rajeshwaran, Department of Civil Engineering, Kalasalingam Academy of Research and Education, Krishnankoil 626126, India, atrajeshwaranucp@gmail.com

G. N. Renganathan, Department of Civil Engineering, Kalasalingam Academy of Research and Education, Krishnankoil 626126, India, harirenga98@gmail.com of construction. As it allows a significant increase of the discharge capacity compared to the discharge capacity of traditional weirs and as its geometry allows easy use on dam crest, the piano-key weir is a suitable mechanism to enhance the safety level of an existing dam. A limited number of studies on piano-key weir is already conducted and at a handful of places, these have been constructed for practical use. The objective of the study is to compare the hydraulic performance of a piano-key weir with an ogee weir and to recognize the causes thereof through the physical inspection.

Consider flow over a weir as shown in Fig. 1. In the figure $d z$ is a small thickness as a depth of $z$ from the top of water surface. Width of the weir is $b$. The velocity of flow through the small area $A=(b \times d z)$ is $v=\sqrt{2 g z}$. Thus the theoretical flow rate through the small area can be written as, $d Q=A \times v=(b \times d z) \times \sqrt{2 g z}$. Integrating the above equation over the full depth results as follows.

$$
\begin{gathered}
Q=\int d Q=\int_{0}^{H} \sqrt{2 g z} \times(b \times d z)=b \sqrt{2 g} \int_{0}^{H} \sqrt{z} d z \\
Q_{t}=\frac{2}{3} b \sqrt{2 g} H^{3 / 2}
\end{gathered}
$$

The quantity $Q_{t}$ is called theoretical discharge and in practice, a discharge coefficient $C_{d}$ (value less than 1) is multiplied with $Q_{t}$ to get the actual discharge $Q_{a}$.

$$
Q_{a}=C_{d} \frac{2}{3} b \sqrt{2 g} H^{3 / 2}
$$

In the above equation, $b$ is a constant and hence by measuring $H$, the discharge $Q_{t}$ can be calculated.

\section{PIANO-KEY WEIR}

The piano-key weir is a type of labyrinth weir having upstream and downstream cantilevers so as to reduce the base width requirement (Fig. 3). In the labyrinth shape or piano-key weir, the effective weir length ( $b$ of equation 1 and 2) is increased by folded arrangement and hence the discharge is also expected to increase. However, the flow direction is not perpendicular to the weir for entire length. Hence, a linear increase in discharge is not expected.

Piano-key weir was first designed in 2001 and very limited literature is available [1-7]. Studies on influence of piano-key weir geometry on the discharge are available in the literature. However, all these studies have limitations and do not answer directly answer the simple questions such as how much could be the increase in discharge. 


\section{EXPERIMENTAL SETUP}

A tilting flume of $2.5 \mathrm{~m}$ long, $0.25 \mathrm{~m}$ wide, and $0.3 \mathrm{~m}$ high was used in this study. A closed circuit water supply system with a pump was used. Water was supplied into the flume through a stilling chamber so as to ensure uniform flow in the flume. The flume body is made of transparent perspex material to expedite observation of flow patterns. The weir models were made of wood and painted for a smooth surface. The lengths of the models were made exactly equal to the width of the flume $(0.25 \mathrm{~m})$ so as to fit exactly in the flume. The water level in the flume was measured using a hook gauge. The actual discharge was estimated from the specific quantity of water accumulated in a collection tank and the time required for the accumulation.
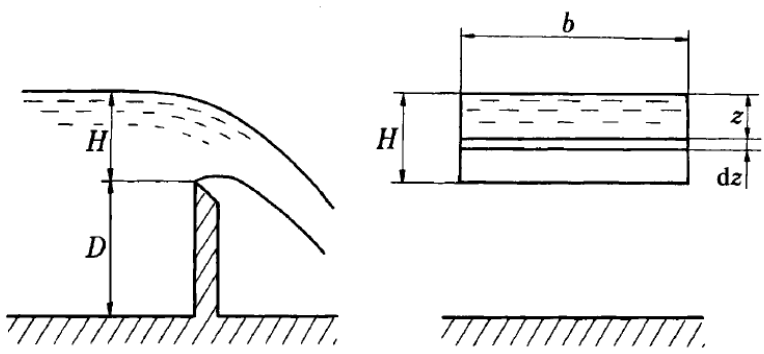

Fig. 1. Flow over a straight weir.

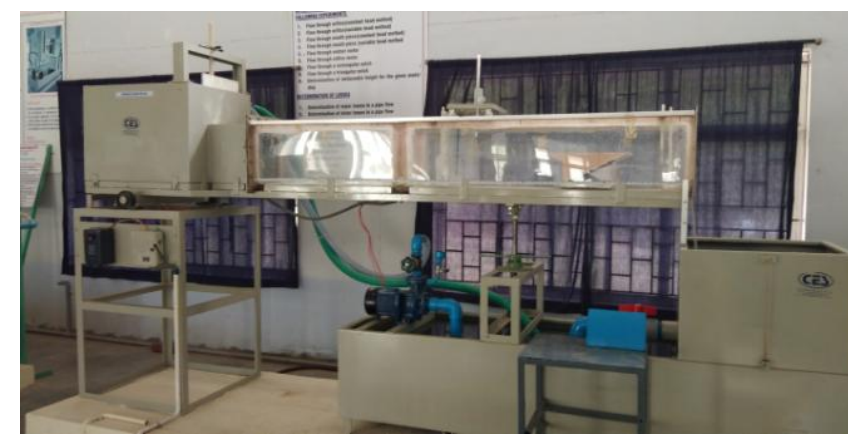

Fig. 2. Tilting Flume.

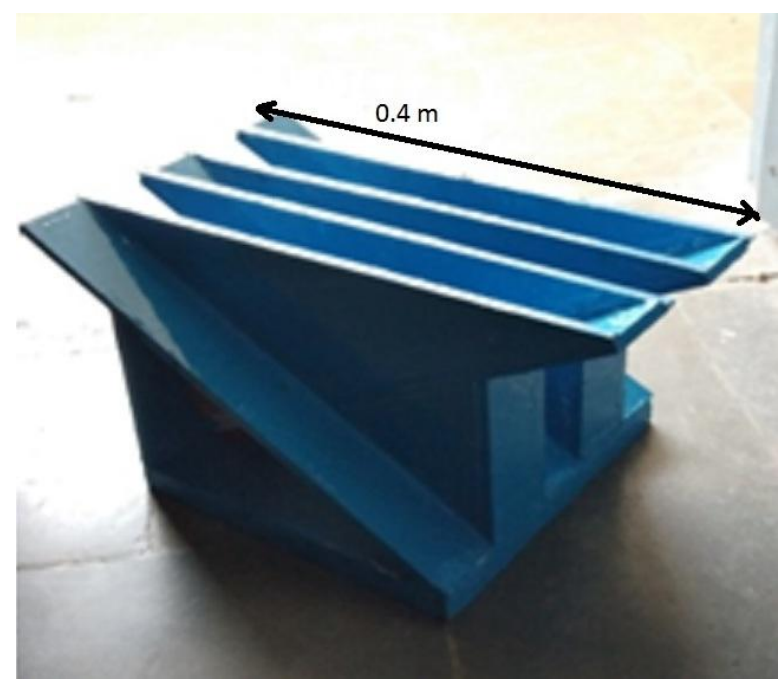

Fig. 3. Piano-key Weir.

Experiments were conducted using an ogee weir and piano-key weir. For a set head causing flow, the discharge over the ogee weir and piano-key weir were compared. The coefficient of discharge of an ogee weir is generally estimated based on the ratio of observed discharge and estimated discharge using equation (1). In this study, for the piano-key weir, the total length of the weir including the folds is used as $b$ and the $C_{d}$ value of piano-key weir was estimated and compared with the $C_{d}$ value of ogee weir. The value of $b$ is taken as $0.25 \mathrm{~m}$ and $1.8 \mathrm{~m}$ respectively for the ogee and piano-key weirs.

\section{RESULTS AND DISCUSSION}

The experimental results of ogee weir and the piano-key weir are presented in tables 1 and 2 . The average velocity of flow in the channel in the case of ogee weir experiments were estimated between $0.015 \mathrm{~m} / \mathrm{s}$ to $0.072 \mathrm{~m} / \mathrm{s}$ and the Froude number was ranging between 0.012 to 0.054 . Similarly in the case of piano-key weir experiments, velocity of flow in the channel was ranging between $0.028 \mathrm{~m} / \mathrm{s}$ to $0.136 \mathrm{~m} / \mathrm{s}$ and the Froude number range was 0.022 and 0.102 .

\section{Table- I: Experimental Results of Ogee Weir}

\begin{tabular}{|c|c|c|c|c|}
\hline No. & $\begin{array}{c}\text { Head } H \\
\text { over weir } \\
(\mathrm{m})\end{array}$ & $\begin{array}{c}Q_{t} \\
\left(\mathrm{~m}^{3} / \mathrm{s}\right)\end{array}$ & $\begin{array}{c}Q_{a} \\
\left(\mathrm{~m}^{3} / \mathrm{s}\right)\end{array}$ & $C_{d}=Q_{d} / Q_{t}$ \\
\hline 1 & 0.010 & 0.00074 & 0.00061 & 0.830 \\
\hline 2 & 0.012 & 0.00097 & 0.00077 & 0.789 \\
\hline 3 & 0.014 & 0.00122 & 0.00094 & 0.771 \\
\hline 4 & 0.019 & 0.00193 & 0.00149 & 0.768 \\
\hline 5 & 0.020 & 0.00209 & 0.00163 & 0.782 \\
\hline 6 & 0.023 & 0.00258 & 0.00204 & 0.793 \\
\hline 7 & 0.025 & 0.00292 & 0.00223 & 0.763 \\
\hline 8 & 0.027 & 0.00328 & 0.00258 & 0.787 \\
\hline 9 & 0.031 & 0.00403 & 0.00327 & 0.811 \\
\hline
\end{tabular}

Table- II: Experimental Results of Piano-key Weir

\begin{tabular}{|c|c|c|c|c|}
\hline No. & $\begin{array}{c}\text { Head } H \\
\text { over weir } \\
(\mathrm{m})\end{array}$ & $Q_{t}$ & $Q_{a}$ & $C_{d}=Q_{d} / Q_{t}$ \\
\hline 1 & 0.010 & 0.00546 & 0.00129 & 0.236 \\
\hline 2 & 0.012 & 0.00718 & 0.00163 & 0.227 \\
\hline 3 & 0.014 & 0.00905 & 0.00204 & 0.226 \\
\hline 4 & 0.019 & 0.01431 & 0.00327 & 0.228 \\
\hline 5 & 0.020 & 0.01545 & 0.00350 & 0.227 \\
\hline 6 & 0.023 & 0.01906 & 0.00446 & 0.234 \\
\hline 7 & 0.025 & 0.02159 & 0.00490 & 0.227 \\
\hline 8 & 0.027 & 0.02424 & 0.00545 & 0.225 \\
\hline 9 & 0.031 & 0.02982 & 0.00700 & 0.235 \\
\hline
\end{tabular}

The average value of $C_{d}$ in the case of ogee weir is 0.788 and this value is 0.229 in the case of piano-key weir. As expected, there is a significant reduction in $C_{d}$ value in the case of piano-key weir. However, piano-key weir discharges more than the ogee weir for a same upstream head and the increase, $100 \times\left(Q_{\text {Piano }}-Q_{\text {Ogee }}\right) / Q_{\text {Ogee }}$, is to the tune of $115 \%$. 


\section{CONCLUSION}

A laboratory setup was prepared to compare a piano-key weir to an ogee weir. Compared to the ogee weir, the piano-key weir with the given configuration discharges a little more than twice for the same head causing flow. Further, the coefficient of discharge of piano-key weir is lower to the tune of 0.3 times the coefficient of discharge of ogee weir. The flow patterns observed indicates the effect of the boundary layer on the flow. Thus, it has been recognized that the width of the piano-keys and number of keys may significantly influence the increase in discharge and coefficient of discharge. Further, because of the inclined bottom of the keys water reflex takes place against the downward flow at the piano-key, and thus the impact of the key-bed slope along with the velocity of flow is to be studied carefully. At higher velocities of flow, boundary effect may be relatively smaller compared to the effect of the key-bed slope.

\section{REFERENCES}

1. R.M. Anderson, B.P. Tullis, "Piano-key Weir hydraulics and labyrinth weir comparison," J. Irrig. Drain. Eng., 2013, vol. 139(3), pp. 246-253.

2. A. Kabiri-Samani, A. Javaheri, "Discharge coefficients for free and submerged flow over Piano-key Weirs," J. Hydraulic Res., 2012, vol. 50(1), pp. 114-120.

3. L.M. Ribeiro, M. Pfister, A.J. Schleiss, J.-L. Boillat, "Hydraulic design of A-type Piano-key Weirs," J. Hydraulic Res., 2012a, vol. 50(4), pp. 400-408.

4. L.M. Ribeiro, M. Bieri, J.-L. Boillat, A.J. Schleiss, G. Singhal, N. Sharma, "Discharge capacity of Piano-key Weirs," J. Hydraulic Eng., 2012b, vol. 138, pp. 199-203.

5. O. Machiels, "Experimental study of the hydraulic behaviour of Piano-key Weirs," PhD thesis. HECE Research Unit, University of Liège, Belgium, 2012. http://hdl.handle.net/2268/128006.

6. O. Machiels, S. Erpicum, B. Dewals, P. Archambeau, M. Pirotton, "Experimental observation of flow characteristics over a Piano-key Weir," J. Hydraulic Res., 2011, vol. 49(3), pp. 359-366.

7. O. Machiels, S. Erpicum, P. Archambeau, B.J. Dewals, M. Pirotton, "Parapet wall effect on Piano-key Weirs efficiency," J. Irrig. Drain. Eng., 2012, vol. 139(6), pp. 506-511.

\section{AUTHORS PROFILE}

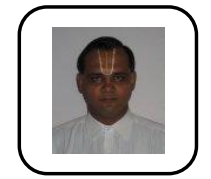

Dr. T.R. Neelakantan is a Senior Professor in Civi Engineering and Director - Accreditation and Ranking at Kalasalingam Academy of Research and Education, Tamilnadu, India. He obtained his Ph.D. degree in Civil Engineering from Anna University in the year 1998. His working experiences are from Anna University, IIT-Madras, SASTRA Deemed University and the University of Kentucky, Lexington, USA. He published more than 60 articles in reputed journals, and handled many government and private funded projects both in India and USA.

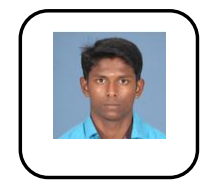

T. Rajeshwaran was a B.Tech. Civil Engineering student (2015-2019) at Department of Civil Engineering, Kalasalingam Academy of Research and Education, Tamilnadu, India.

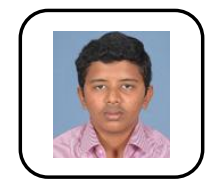

G. N. Renganathan was a B.Tech. Civil Engineering student (2015-2019) at Department of Civil Engineering, Kalasalingam Academy of Research and Education, Tamilnadu, India. 